\title{
(brundri $\mathfrak{i}$ \\ des deutidgen Ulrheberredits \\ und Erfinderredits
}

fiir Studierende

pon

\section{Dr. friedriđ Ģellmatm,}

o. D. Brofeffor Der Rectte in München

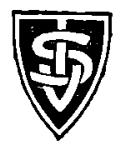

Mūn丸en und Berlin 1909.

3. Sameiter Berlag (Utrthur Sellier). 


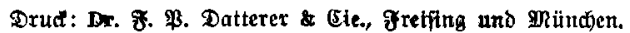

